Innlegg på inntil $\mathbf{4 0 0}$ ord lastes opp i http://mc.manuscriptcentral.com/tidsskriftet.

Redaksjonen forbeholder seg retten til å foreta redaksjonelle endringer.

Forfattere av vitenskapelige artikler har tilsvarsrett (jf. Vancouver-gruppens regler).

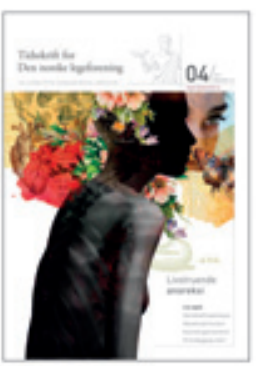

\section{Nakkeskjevhet hos barn bør utredes!}

I en kommentar i Tidsskriftet nr. 4/2011 (1) oppfordrer Charlotte Sinding-Larsen og medarbeidere til kritisk å vurdere de kildene som finnes om øvre nakkeledd-indusert symmetriforstyrrelse (Kopfgelenk-induzierte Symmetrie Störung, KISS) hos spedbarn.

Vi er enige $i$ at det er viktig å være kritisk når det gjelder diagnosebruk. Men det er også viktig å ha blikk for ulike differensialdiagnoser. Vi mener det bør være del av den kliniske grunnkompetansen å oppdage eller differensialdiagnostisere f.eks. en bevegelsesforstyrrelse i cervikalcolumna hos barn.

Sinding-Larsen og medarbeidere mener man bør avvente utredning ved kliniske funn, fordi de kan være «ufarlige og forbigående» (1). Dette er vi uenige i. Vi mener slike funn bør utredes nærmere ved hjelp av nevrologiske og funksjonelle tester, ev. også ved radiologisk undersøkelse, senest etter at banene for viljestyrte bevegelser aktiveres. Cervikalcolumnas funksjon er av vesentlig betydning for spedbarnets kroppsholdning og for de oppgaver barnets sensomotoriske apparat har (2). Enkle kliniske tester, som også helsesøstre kan gjøre, kan gi en pekepinn om videre utredning, f.eks. forsøk på å utløse tonisk labyrintrefleks eller landaureaksjon - der hodet bøyes passivt i ventralfleksjon. Finner man ingen utviklingsforstyrrelser eller typiske symptomer, bør spontanutviklingen av de cervikale bevegelsesinnskrenkningene følges nøye. Kommentarforfatterenes påstand om at bevegelsesinnskrenkningene «kan være ufarlig og forbigående» (1) er tvilsom, da man ikke har noen longitudinelle randomiserte studier av tilstandens utvikling.

Etter vår mening bør ethvert avik man finner i bevegelsesmønster eller kroppsholdning etter tre måneders alder være gjenstand for nøyaktig diagnostikk og ev. behandling. Vår erfaring er at manuellmedisinsk diagnostikk og KISS-konseptet kan gi god hjelp, samtidig som man tilbyr terapeu- tisk intervensjon. Reversible segmentale funksjonsforstyrrelser kan ses ved uspesifikke symptomer. I henhold til KISS-konspetet kan de ha sitt utspring i et forstyrret, stereotypt, proprioseptivt utløsningsmønster i den øvre nakkeregionen. Bakgrunnen er påvirkninger på cervikal-diencefale og cervikal-mesencefale projeksjoner og på de toniske nakke- og stillingsreflekser (3).

Forfatterne mener man har sett upåfallende funn hos barn som er under KISSbehandling og at friske barn behandles. Vi mener dette er fordi behandlingen er effektiv.

Barn med symptomer bør alltid bli gjenstand for grundig klinisk unders $ø$ kelse og ivaretas med kompetanse og nysgjerrighet. Foreldrenes erfaringer spiller en like stor rolle som helsepersonellets medisinske erfaringer. En ensidig vektlegging av hva som er dekket av (nødvendige) randomiserte kliniske studier, kan føre til et begrenset blikk på nye diagnostiske og terapeutiske konsepter. Medisinen bygger først og fremst på individuelle erfaringer (4).

\section{Robby Sacher \\ Dortmund \\ Ute Imhof \\ Oslo}

Robby Sacher (f. 1963) er dr.med. og spesialist i allmennmedisin og i Manuelle Medizin (med vekt på utviklingsnevrologi hos barn).

Ingen oppgitte interessekonflikter.

Ute Imhof (f. 1964) er fysioterapeut og spesialist i barnefysioterapi.

Ingen oppgitte interessekonflikter.

\section{Litteratur}

1. Sinding-Larsen C, Bjørnstad R, Grøgaard J. KISS - forklaringen på mange plager hos små barn? Tidsskr Nor Legeforen 2011; 131: 338-9.

2. Sacher R. Angeborene Fremdreflexe. München: Elsevier, 2011.

3. Gutmann G. Funktionelle Pathologie und Klinik de Wirbelsäule. Die Halswirbelsäule. Bd. 1, del 2. I: Gutmann G, Biedermann H, red. Allgemeine funktionelle Pathologie und klinische Syndrome. Stuttgart: Fischer, 1984

4. Hoppe J-D. Statt Programm-Medizin: Mehr Vertrauen in die ärztliche Urteilskraft. Deutsches Ärzteblatt 2005; 104: A-943/B-799/C-747.

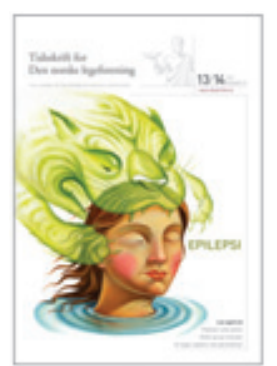

\section{Dislokerte albuefrakturer i en global verden}

I Tidsskriftet nr. 13-14/2011 påpeker Bøhler (1) at størsteparten av verdens befolkning ikke har tilgang til den behandling vi har anbefalt ved dislokerte albuefrakturer hos barn, nemlig lukket reponering og pinnefiksering under gjennomlysning (2). Hans sykehus i Nepal har ikke gjennomlysningsmaskin, og alternativet er åpen kirurgi dersom lukket reponering ikke er vellykket. Han etterlyser gjennomførbare behandlingsmuligheter tilgjengelig for flest mulig barn, i stedet for finjustering av kirurgiske teknikker. Vi er ydmyke overfor de utfordringer Bøhler møter i sin kliniske hverdag. Hans tankevekkende innlegg minner oss om at verdens goder er urettferdig fordelt.

En norsk studie viste at det kliniske resultatet etter strekkbehandling er sidestilt med perkutan pinning (3). Strekkbehandling har den fordel at det ikke krever røntgengjennomlysning. Men strekkbehandling er dyrere enn pinning, fordi sykehusopphold er så dyrt (4). Om dette også er tilfellet i Nepal, vet vi ikke, men det er naturligvis uinteressant så lenge pinning ikke er mulig. Vi mener at strekkbehandling bør være neste behandlingsvalg ved Gartland III-frakturer. Det er fordi lukket reponering alene gir større risiko for den invalidiserende tilstanden Volkmans iskemi (5). Bøhler refererer til en artikkel fra India, der man har relativt gode resultater med lukket reponering av Gartland III-frakturer (6). Antallet slike frakturer i denne studien var 40, slik at det ikke var mulig å vurdere risikoen for Volkmans iskemi, som heldigvis er en sjelden komplikasjon.

Bøhler skriver at det er vanskelig å motivere pasientene til strekkbehandling, fordi det krever lang liggetid. Kanskje kunne ambulerende strekkbehandling være et alternativ (7)? På den måten kan pasienten behandles i hjemmet.

Vi har for øvrig inntrykk av at konservativ bruddbehandling er en legekunst som er i ferd med å gå tapt. Bøhlers innlegg fikk 
oss til å børste støv av Charnleys lærebok i konservativ behandling, som beskriver reponering og gipsbehandling av brudd som vi i dag aldri ville nølt med å operere (8).

\section{Per-Henrik Randsborg}

Akershus universitetssykehus

Einar Andreas Sivertsen

Martina Hansens hospital

Per-Henrik Randsborg (f. 1973) er spesialist i ortopedisk kirurgi og klinisk stipendiat ved Universitetet i Oslo.

Ingen oppgitte interessekonflikter.

Einar Andreas Sivertsen (f. 1968) er dr.med. og assistentlege.

Ingen oppgitte interessekonflikter.

Litteratur

1. Bøhler E. Det beste i Norge - ikke alltid det beste i verden. Tidsskr Nor Legeforen 2011; 131: 1280.

2. Randsborg PH, Sivertsen EA. Suprakondulære humerusfrakturer hos barn. Tidsskr Nor Legeforen 2011: 131: 349-52

3. Young S, Fevang JM, Gullaksen $G$ et al. Deformity and functional outcome after treatment for supracondylar humerus fractures in children: a 5 - to 10 -year follow up of 139 supracondylar humerus ractures treated by plaster cast, skeletal traction or corssed wire fixation. J Child Orthop 2010; 4: 445-53

4. Prietto CA. Supracondylar fractures of the humerus. A comparative study of Dunlop's traction versus percutaneous pinning. J Bone Joint Surg Am 1979; 61: 425-8.

5. Henrikson B. Supracondylar fracture of the humerus in children. A late review of end-results with special reference to the cause of deformity disability and complications. Acta Chir Scand Suppl $1966 ; 369: 1-72$

6. de Gheldere A, Bellan D. Outcome of Gartland type II and type III supracondylar fractures treated by Blount's technique. Indian J Orthop 2010; 44: $89-94$

7. Kargaard J. The treatment of supracondylar fractures by ambulatory traction. Trop Doct 1994; 24 $20-1$

8. Charnley J. The closed treatment of common fractures. Cambridge: Cambridge University Press, 1950

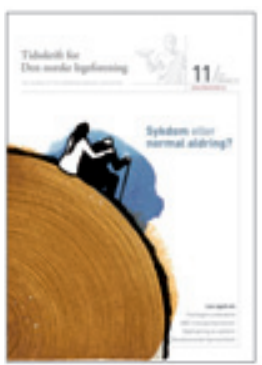

\section{Vi har gode nok data}

Bente Mikkelsen, administrerende direktør i Helse Sør-Øst, har i et brev til redaktøren i Tidsskriftet nr. 11/2011 (1) bemerkninger til undertegnedes kommentar Forbedring krever solide data i Tidsskriftet nr. 7/2011 (2), der jeg kritiserte at Helse Sør-Østs mål er basert på uegnede data, nemlig prevalenstall.
Det er prisverdig at Helse Sør-Øst trekker smittevernet frem i lyset gjennom etablering av eget mål og at man for første gang har gjort det målbart. Slik satsing på pasientsikkerhet er tilpasset utviklingen internasjonalt, som har ført til føringer fra WHO (3).

Vi kan være enige om at prevalenstall er en enkel målemetode og at tallene er allment kjent, i tillegg til at sykehusene har rikelig med historiske data. Tallene mangler dog spesifisitet og kan kun møtes av uspesifikke tiltak. Det er derimot ikke riktig at historikk er forbeholdt prevalenstall: Registrering av insidenstall for kirurgiske inngrep ble etablert for flere år siden (4). Dermed har enhver sykehusledelse tilgang til relevante data for forbedring av spissede prosesser egnet til å redusere risikoen rundt våre mest utsatte pasientgrupper.

Smittevernavdelingen i Vestre Viken arbeider etter internasjonale retningslinjer med risikostyring og etablering av egnede mål $(5,6)$ for all klinisk virksomhet. Målene ble nylig forankret i styrets sentrale kvalitetsutvalg. Vi har valgt klinikkvise mål for å møte ulik smitterisiko i virksomheten, og postoperative sårinfeksjoner er hovedsatsningsområdet innenfor kirurgien. Kvinnebarn-klinikken etablerer nå mål på $3 \%$ for sårinfeksjoner etter keisersnitt. Dette stramme målet er resultatet av forbedringsarbeid gjort ved Bærum sykehus, der vi har redusert forekomsten til vesentlig under landsgjennomsnittet på $8 \%$. Tilsvarende for ortopedi (hofteproteseinfeksjoner) og colonkirurgi (anastomoselekkasjer).

For indremedisin gjelder annen smitterisiko. Den måles derfor på antibiotikabruken, med oppfordring til bruk av smalspektrede midler til fortrengsel for de mer moderne. I psykiatrien legges det vekt på blodsmitteuhell. Tilpasset det brede målet fra Helse Sør-Øst gjennomføres det håndhygienekampanjer, der smykkebruk står sentralt.

Hovedideen i smittevernet har hele veien vært at ledelsen kan igangsette forbedringsarbeid ved manglende måloppnåelse. Smittevernavdelingen hjelper til ved å tilby solid dataleveranse.

Måldokumentet til Helse Sør-Øst er såpass åpent og krever så mye lokal tilpasning at man risikerer at statistikktallene ikke nødvendigvis kan settes sammen til en helhet eller benyttes til målformulering. Denne betraktningen blir antakelig enda verre på nasjonalt plan. Derfor burde de regionale helseforetakene samordne måldokumentene til nasjonale mål.

Selv om Helse Sør-Øst og Vestre Viken har ulik tilnærming til etablering av mål innen smittevernet, har vi alle et felles ønske om å redusere unødig risiko omkring pasientene våre. Det blir spennende å følge den forbedringen av mål som er påkrevd i Helse Sør-Øst.

\section{Mette Walberg}

Bærum sykehus
Mette Walberg (f. 1958) er spesialist

i medisinsk mikrobiologi og smittevernoverlege i Vestre Viken.

Ingen oppgitte interessekonflikter.

Litteratur

1. Mikkelsen B. Forbedring krever gode data. Tidsskr Nor Legeforen 2011: 131: 1072.

2. Walberg M. Forbedring krever gode data. Tidsskr Nor Legeforen 2011; 131: 670 .

3. WHO guidelines for safe surgery 2009. http://whqlibdoc.who.int/publications/2009/ 9789241598552 eng.pdf (15.6.2011).

4. NOIS-registerforskriften. Forskrift av 17. juni 2005 nr. 611. www.lovdata.no/for/sf/ho/ xo-20050617-0611.html (15.6.2011).

5. NS-ISO 9001: 2008 om krav til styring av kvalitet. www.standard.no/Global/PDF/Kvalitet/ Kvalitetsstyring\%20februar\%202009\%20samlet $\%$ 20web.pdf (15.6.2011).

6. DS 2450: 2001 Styring af infektionshygiene krav til ledelsessystemet. Charlottenlund: Dansk Standard, 2001

Engelsk oversettelse av hele innlegget på www.tidsskriftet.no

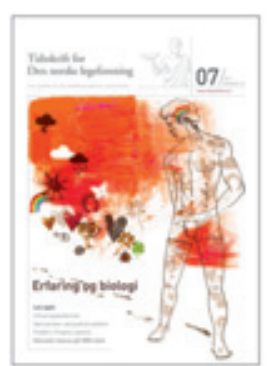

\section{Vi tar ryggpasienten på alvor}

Håkon Lie er en nestor i norsk ryggmedisinsk miljø og initierte i sin tid opprettelsen av den tverrfaglige Norsk Forening for Ryggforskning. Med denne bakgrunnen er det vanskelig å forstå at han i tidsskriftet nr. 7/2011 ikke vil akseptere moderne ryggforskning, som danner grunnlaget for de nasjonale tverrfaglige retningslinjer for ryggbehandling (1). Disse er basert på systematisk gjennomgang av over 10000 originalartikler og har graderte anbefalinger som fullt ut er overensstemmende med internasjonale retningslinjer for ryggbehandling (2).

Det er etter 20 års intens ryggforskning ikke dokumentasjon for en subklassifisering av den store gruppen $-85 \%$ - med uspesifikke ryggplager. Lie bør være kjent med at det har vært gjort betydelige forsøk på å etablere slik subklassifisering, og en helt fersk doktoravhandling med dette som tema er nylig presentert (3). Verken denne eller radiologiske Modic-forandringer (4) har imidlertid vist seg klinisk og metodologisk anvendelige til å endre den etablerte diagnostiske inndeling.

Når Lie eller andre presenterer studier basert på subklassifisering som kan lede til en definert behandling som er signifikant 